\title{
Moebius-Poland syndrome and hypogonadotropic hypogonadism
}

\author{
Diego López de Lara • Jaime Cruz-Rojo • \\ Jaime Sánchez del Pozo • Maria Elena Gallego Gómez • \\ Gregorio Lledó Valera
}

Received: 20 November 2006 / Accepted: 13 March 2007 / Published online: 31 March 2007

(C) Springer-Verlag 2007

Keywords Moebius syndrome · Poland syndrome . Hypogonadotropic $\cdot$ Hypogonadism

\section{Case report}

A male infant was born at 39 weeks of gestation, with birth weight $(3.1 \mathrm{~kg})$ and body length $(49 \mathrm{~cm})$ (both 50th percentile). The occipitofrontal circumference was $33 \mathrm{~cm}$ (25th percentile). The newborn's face was inexpressive due to complete facial diplegia, bilateral ophthalmoplegia with impairment of the vertical gaze of the right eye, palpebral ptosis, a carp-shaped mouth, and a high-arched palate. Muscle and skeletal abnormalities were also apparent, including the absence of the pectoralis major and trapezius muscles, as well as left cubitus valgus; left hand was hypoplastic and showed 5th finger clinodactyly. These features prompted the diagnosis of Moebius-Poland syndrome. No previous cases were known in the patient's family. Clinical examination revealed no other dysmorphic features except for micropenis. The karyotype was normal (46 XY). During follow-up, a mild psychomotor delay was confirmed by Denver Developmental Screening Test-II. Cortical-subcortical atrophy with no other structural abnormalities was observed in magnetic resonance imaging (MRI) of the brain. Delayed puberty was recorded when

D. López de Lara $(\bowtie) \cdot J$. Cruz-Rojo · J. Sánchez del Pozo • M. E. Gallego Gómez · G. Lledó Valera

Servicio de Endocrinologia Pediatrica, Hospital 12 de Octubre, Avda de Córdoba S/N,

28041 Madrid, Spain

e-mail: dldlara@yahoo.es the patient was 15 years of age (Tanner stage I was recorded after physical examination). The testicular volume (measured using a Prader orchidometer) was $2 \mathrm{ml}$. Anosmia-tested by a standard olfactory test (CCCRC)- was not present. An endocrinological investigation revealed low baseline serum FSH $(0.5 \mathrm{mU} / \mathrm{ml}), \mathrm{LH}(0.1 \mathrm{mU} / \mathrm{ml})$ and testosterone $(2 \mathrm{ng} / \mathrm{dl})$ levels. To confirm the suspected hypogonadotropic hypogonadism, a gonadotrophin releasing hormone stimulation test was performed and a very subnormal response obtained (after $180 \mathrm{~min}$ and $24 \mathrm{~h} \mathrm{FSH}$ concentrations were $3.5 \mathrm{mU} / \mathrm{ml}$ and $0.7 \mathrm{mU} / \mathrm{ml}$, respectively, and LH concentrations $0.7 \mathrm{mU} / \mathrm{ml}$ and $0.2 \mathrm{mU} / \mathrm{ml}$, respectively). GH, TSH, and ACTH levels were normal. A further MRI scan of the brain showed no pathological lesions in the hypothalamus or pituitary gland. With a diagnosis of hypogonadotropic hypogonadism established, the child was treated with gonadotrophic hormone followed by depot preparations of testosterone. The patient eventually reached a normal weight and height and attained full sexual development (final testicular volume 6-8 $\mathrm{ml}$ ).

\section{Discussion}

The usual diagnostic criteria for Moebius syndrome include congenital facial palsy with impaired ocular abduction $[1,2,4,6]$. Nevertheless, in a thorough review, Verzijl et al. reported that abducens nerve palsy is not always present [6]. Vertical gaze palsy was recorded in the right eye of the present patient, suggesting involvement of the 3rd cranial nerve (Fig. 1). MRI scans often demonstrate anomalies of the posterior fossa in patients with Moebius syndrome, and it has been proposed that the latter be understood as a complex congenital anomaly affecting the 


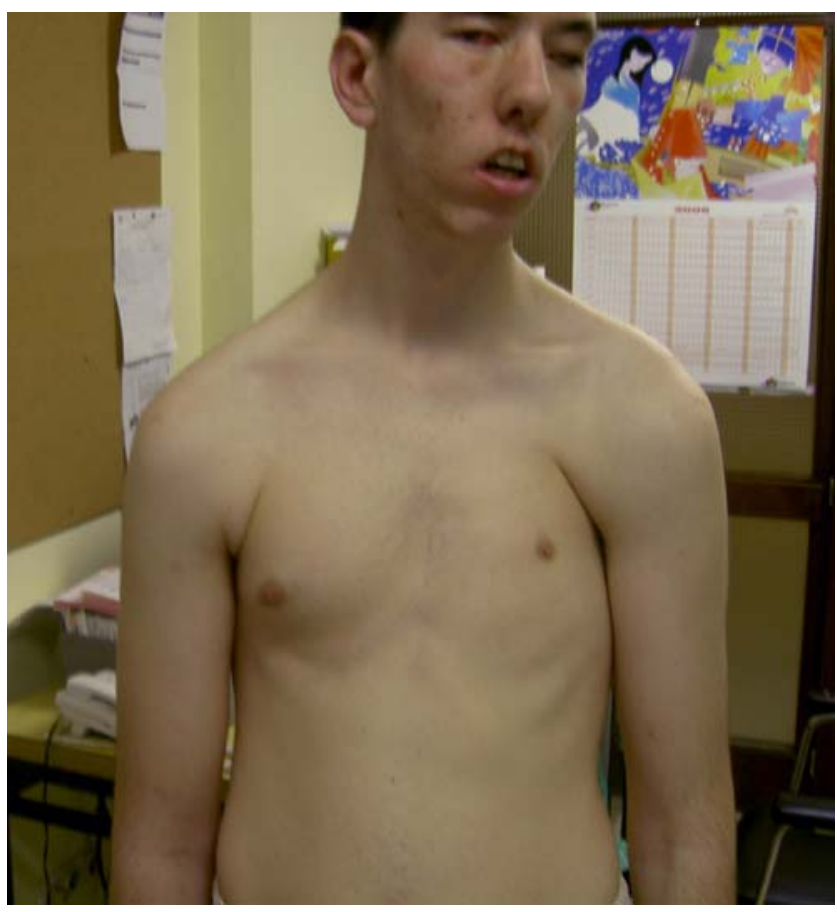

Fig. 1 Patient photo

rhombencephalon [6]. The present patient, however, showed no such anomalies. In addition to the main signs, more than half of all patients with Moebius syndrome have other anomalies, usually limb defects $[1,3]$. The specific combination of both Moebius syndrome and Poland syndrome - a rare congenital anomaly characterised by pectoralis muscle defect and ipsilateral hand abnormalities - has been reported before, and is then referred to as Moebius-Poland syndrome [5]. Some authors suggest it may represent a single developmental condition that may be due to the variable expression of a single gene or involve contiguous genes [6].

Hypogonadotropic hypogonadism is unusual in Moebius syndrome [1-3]. The present patient is only the 7 th case reported to date, and the first with Moebius-Poland syndrome.

\section{References}

1. Baraitser M, Rudge P (1996) Moebius syndrome, an axonal neuropathy and hypogonadism. Dysmorph 5:351-355

2. Brackett LE, Demers LM, Mamourian AC, Ellenberger $\mathrm{C} \mathrm{Jr}$, Santen RJ (1991) Moebius sequence in association with hypogonadotropic hypogonadism (case report). J Endocr Invest 14:599607

3. Jennings JE, Costigan C, Reardon W (2003) Moebius sequence and hypogonadotrophic hypogonadism. Am J Med Genet 123:107-110

4. McDermot KD, Winter RM, Taylor D, Baraitser M (1991) Oculofacial bulbar palsy in mother and son: review of 26 reports of familial transmission within the "Moebius spectrum of defects". J Med Genet 28:18-26

5. Parker DL, Mitchell PR, Holmes GL (1981) Poland-Moebius syndrome. J Med Genet 18:317-320

6. Verzijl HTFM, van der Zwaag B, Cruysberg JRM, Padberg GW (2003) Moebius syndrome redefined: a syndrome of rhombencephalic maldevelopment. Neurology 61:327-333 